\title{
Infiltrating Bladder Urothelial Carcinoma with Squamous Differentiation
}

National Cancer Institute

\section{Source}

National Cancer Institute. Infiltrating Bladder Urothelial Carcinoma with Squamous

Differentiation. NCI Thesaurus. Code C39816.

An invasive transitional cell carcinoma of the bladder that exhibits squamous

differentiation. 